\title{
Iliac crest and femoral bone marrow as the source of plastic-adherent cells
}

\author{
Phedy, ${ }^{1}$ Ismail H. Dilogo, ${ }^{2}$ Ahmad A. Jusuf, ${ }^{3}$ Erica Kholinne, ${ }^{1}$ Zuhri Efendi ${ }^{1}$ \\ ${ }^{1}$ Resident at Departemen of Orthopaedic dan Traumatology, Faculty of Medicine, University of Indonesia, Jakarta, Indonesia \\ ${ }^{2}$ Consultant at Departemen of Orthopaedic dan Traumatology, Faculty of Medicine, University of Indonesia, Jakarta, Indonesia \\ ${ }^{3}$ Consultant at Department of Histology, Faculty of Medicine, University of Indonesia
}

\begin{abstract}
Abstrak
Latar belakang: Banyak penelitian yang menggunakan krista iliaka sebgai donor sel punca mesenkimal. Pada kasus fraktur tulang panjang, pengambilan sumsum tulang dari situs fraktur memberikan banyak keuntungan. Akan tetapi, sumsum tulang panjang yang tergolong sebagai sumsum kuning mengandung banyak sel lemak sehingga dipercaya mengandung jumlah sel punca yang lebih sedikit daripada sumsum merah. Karena itu, panelitian ini bertujuan untuk membandingkan potensi sumsum merah dan sumsum kuning sebagai donor sel punca mesenkimal.

Metode: Sumsum tulang dari 8 ekor kelinci Flemish giant jantan diaspirasi dari krista iliaka dan batang femur. Sel mononuklear diisolasi dari asprirat dan diekspansi dalam medium DMEM rendah glukosa. Setelah 8 minggu, sel dipanen dan dihitung dengan hemositometer Neubauer. Perbandingan jumlah sel antara kedua situs dianalisis dengan menggunakan uji t-test.

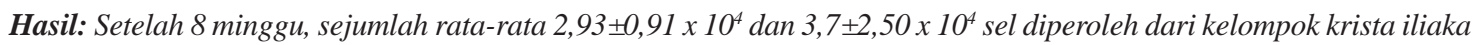
dan batang femur. Tidak ada perbedaan statistik yang bermakna antara kedua kelompok. $(p=0,45)$.

Kesimpulan: Sel yang melekat pada plastik dapat diisolasi dan diekspansi dari krista ilaka maupun batang femur. (Med J Indones 2011; 20:100-4)
\end{abstract}

\begin{abstract}
Background: Many studies have used iliac crest as the source of mesenchymal stem cells. In cases of long bone shaft fracture, obtaining marrow from the fracture site offers more advantages. Nevertheless, due to the high number of fat cells in long bones, the yellow marrow of long bones is believed to contain lower number of mesenchymal stem cells than red marrow. Therefore the aim of this study is to compare the potency between red and yellow marrow as the donor site for the isolation of mesenchymal stem cell.

Methods: Bone marrow of eight giant Flemish rabbits was aspirated from the iliac crest and femoral shaft. Mononuclear cells were isolated from both aspirates and expanded in low glucose DMEM. After eight weeks, the cells were harvested and counted using improved Neubauer hemocytometer. Comparison of the cell number between the two donor sites was then performed by t-test.

Results: After 8 weeks, an average number of $2.93 \pm 0.91 \times 10^{4}$ and $3.7 \pm 2.50 \times 10^{4}$ cells were obtained from the iliac and femoral group respectively. No statistically significant difference was found between those two groups $(\mathrm{p}=0.45)$.

Conclusion: Plastic-adherent cells can be isolated and expanded from both iliac crest and femoral shaft. (Med $\boldsymbol{J}$ Indones 2011; 20:100-4)
\end{abstract}

Key words: plastic-adherent cells, red marrow, yellow marrow

Many studies reported mesenchymal stem cell (MSC) to play an important role in fracture healing. ${ }^{1,2}$ Lee et al. reported improved bone healing in non-union fracture in a dog, ${ }^{1}$ while Kon et al. reported bone healing acceleration in critical-size defects of sheep long bones. ${ }^{2}$ Most studies didn't report the source of the stem cells, but some of them used red marrow. ${ }^{1,3}$ Although red marrow can be obtained easily from the iliac crest, in the case of long bone shaft fracture however, obtaining marrow from the fracture site offers more advantages. It requires less additional procedure, faster, and eliminates donor site morbidity.

Unfortunately, marrow of the long bone is considered as yellow marrow. Yellow marrow contains more lipid than stromal cells and therefore is believed to have lower potency compared to red marrow if it is used as the source of stem cells. Nevertheless, to our knowledge, no study has addressed the issue. We therefore compared the potency of yellow to red marrow as the source of mesenchymal stem cells.

\section{METHODS}

Ethical clearance was obtained from the Ethical Committee of Faculty of Medicine, University of Indonesia prior to the study. Eight giant Flemish rabbits weighted $\pm 2900 \mathrm{~g}$ (Table 1) were included in the study.

\section{Bone marrow aspiration procedure}

After anesthetized, the femoral shaft was surgically exposed and the cortex was drilled using a 1.5 drill bit until it was thin enough for a 14-gauge syringe to be inserted to aspirate one $\mathrm{ml}$ of its marrow. Another one $\mathrm{ml}$ of marrow was aspirated using 14-gauge syringe percutaneously from the iliac crest. 


\section{Culture of aspirated cells}

Cell culture was performed at the Institute of Human Virology and Cancer Biology, Jakarta during February and March 2010.

Each aspirate was diluted 1:1 with phosphate buffered saline (PBS) (Gibco, Grand Island, New York) and centrifuged at $2500 \mathrm{~g}$ for 15 minutes at $20^{\circ} \mathrm{C}$. The pellet was then resuspended into a $25 \mathrm{~mL}$ TC-flask in $8 \mathrm{ml}$ low glucose Dulbecco's modified Eagles medium (Gibco, Grand Island, New York) containing 1g/L D-glucose, L-glutamine, $110 \mathrm{mg} / \mathrm{L}$ sodium pyruvate, and $10 \%$ fetal bovine serum (Gibco, Grand Island, New York); and incubated at $37^{\circ} \mathrm{C}, \mathrm{O}_{2}$ flow of $20 \%$ and $\mathrm{CO}_{2}$ of $5 \%$. The cultures were examined after one week, and every three days. At the end of the first week, non-adherent cells were discarded and the adherent cells were thoroughly washed twice with PBS. Fresh complete medium was added and replaced every 3 days.

\section{Data collection and analysis}

After 8 weeks, the culture was harvested and cells from each donor site were counted blindly using improved Neubauer hemocytometer. The data was noted, tabulated and mean $\pm \mathrm{SD}$ for each group was calculated. A student t-test was performed using STATA v.10 (StataCorp, Texas, Amerika) to compare the mean between those two groups.

\section{RESULTS}

At the time of culture, mononuclear cells were covered by red blood cells (Figure 1). After discarding nonadherent cells, only cells adhered to plastic remained. They exhibited fibroblast-like morphology. After 4 week culture, the number of cells increased in both groups (Figure 2). The density of the cells increased rapidly until the eighth week (Figure 3). At the eighth week, the culture yielded $2.93 \pm 0.91 \times 10^{4}$ and $3.66 \pm 2.50 \times 10^{4}$ cells for the iliac crest and femoral shaft respectively. Cell counts for each donor site were shown in table 1. Statistical analysis showed no difference between those donor sites $(p=0.45)$.

Table 1. Weight of the donor and cell counts after 8 weeks of culture (in $10^{4}$ cells)

\begin{tabular}{|c|c|c|c|}
\hline & \multirow{2}{*}{ Weight (g) } & \multicolumn{2}{|c|}{ Cell count } \\
\hline & & Iliac crest & Femoral shaft \\
\hline & 2100 & 4 & 5 \\
\hline & 2250 & 1.25 & 1.25 \\
\hline & 3750 & 2.5 & 1.25 \\
\hline & 3500 & 3.5 & 6.75 \\
\hline & 2800 & 3.75 & 7.5 \\
\hline & 3350 & 3.4 & 1.5 \\
\hline & 3000 & 2.5 & 3.5 \\
\hline & 2450 & 2.5 & 2.5 \\
\hline Mean & 2900 & 2.93 & 3.66 \\
\hline
\end{tabular}
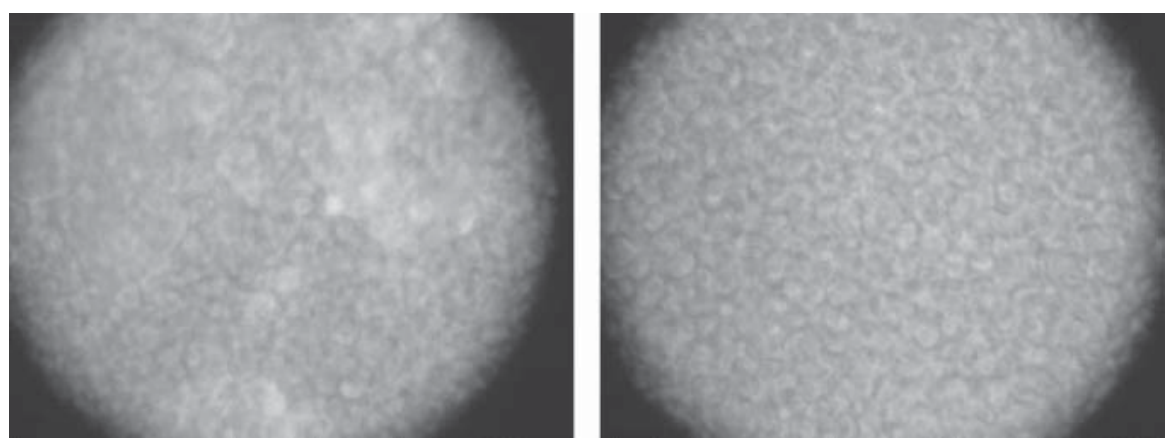

Figure 1. Cells at the time of culture: left= iliac crest, right= femoral shaft. At the time of culture, the mononuclear cells were covered by red blood cells. All magnifications $x 40$.
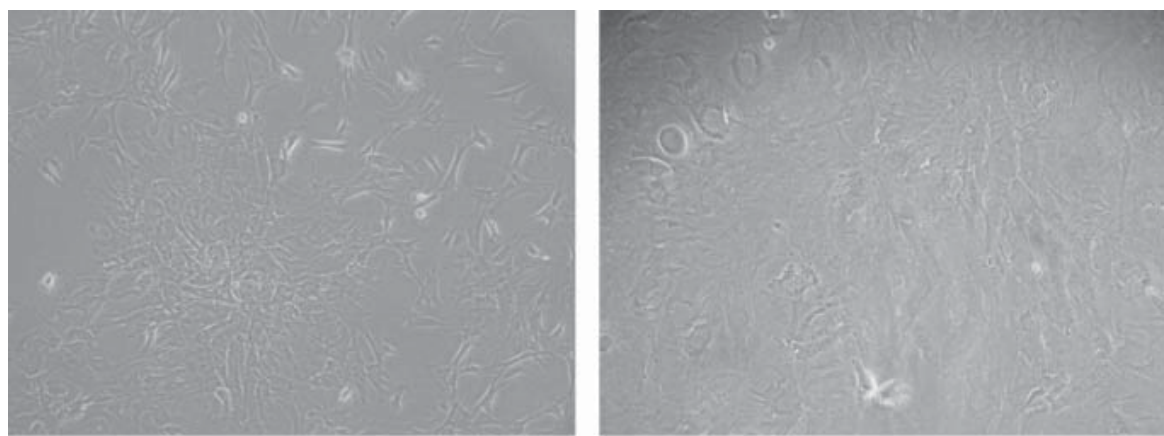

Figure 2. Cells 4 weeks after culture: left= iliac crest, right= femoral shaft. Morphological changes toward spindle-shape were observed in both groups. All magnifications $x 40$. 

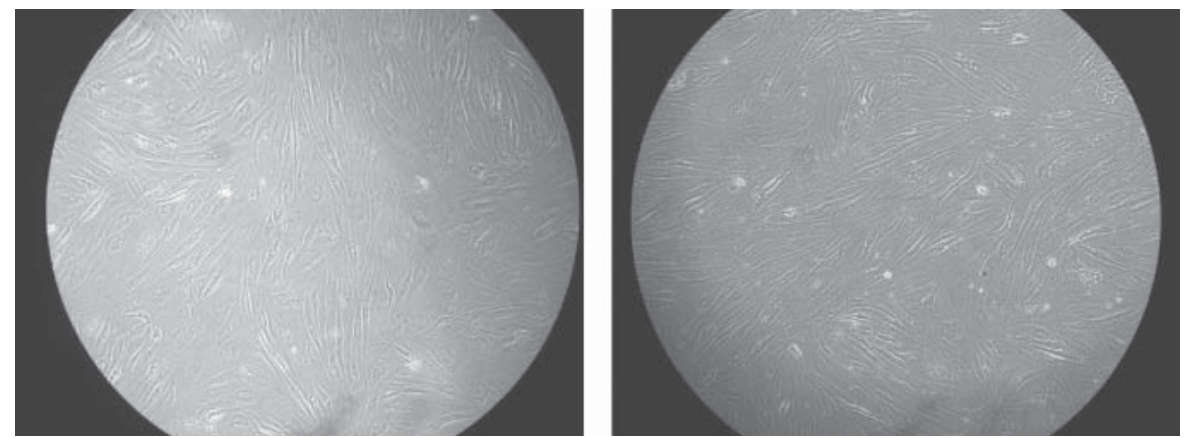

Figure 3. Cells 8 weeks after culture; left=iliac crest, right=femoral shaft. At the 8th week, spindled-shaped cells adhered to plastic were observed in both groups. Both had high density. All magnifications are 40 times.

\section{DISCUSSIONS}

In our study, the two procedures by which we performed marrow aspiration slightly differed, i.e. aspiration from the iliac crest was performed percutaneously, while for femoral shaft was done by surgery. Fennema et al. reported that different strategy of bone marrow aspiration would lead to different quantity of mesenchymal stem cells. ${ }^{4}$ In real clinical settings, it is possible to obtain a percutaneous aspiration of marrow from the iliac crest. On the other hand, percutaneous marrow aspiration from intact femoral shaft is almost impossible due to the thick cortices of the bone, except in the cases of fracture where the marrow of the bone is usually exposed.

We observed that closed aspiration of bone marrow from the iliac crest resulted in more bleeding than open aspiration of bone marrow from the femoral shaft. Since concentration of the mesenchymal stem cells in peripheral blood is much lower than that in the bone marrow, the yield of MSC will definitely lower if more blood is aspirated. ${ }^{4}$

Fennema et al. also reported that at least $8 \mathrm{ml}$ collection volumes of bone marrow aspirates were required to reduce the risk of obtaining aspirates with lower cell numbers. ${ }^{4}$ However, this result is only valid for human subject. In animal models, no study has reported the recommended volume of aspiration to yield adequate MSC. In our study, only $1 \mathrm{~mL}$ of bone marrow was aspirated.

In this study, we were able to isolate the plasticadherent cells from both iliac crest and femoral marrow. We supposed that these cells were mesenchymal stem cells, since mesenchymal stem cells adher to plastic and exhibit fibroblast-like morphology, similar to that observed in our study. ${ }^{5,6}$ Iwakura et al. reported that fibroblastic adherent cells were consistently positive for mesenchymal stem cell related markers and differentiation capacity. ${ }^{7}$ However, to confirm them as mesenchymal stem cells, surface antigen expression and multi-lineage differentiation capacity should be tested.
Isolation of MSC from the femoral marrow has been investigated before by Leonardi et al. and Caipetti et al. ${ }^{89}$ Leonardi et al. reported that femoral marrow was highly effective in proliferating and differentiating along the osteogenic lineage. ${ }^{8}$ Caipetti et al. found that MSC isolated from the femur of adult patients consistently maintain an osteogenic potential. ${ }^{9}$

In this study, the expansion rate of the cultured cells was lower than that reported by other studies. ${ }^{10,11}$ Both et al. reached 200 million cells in 12-21 days for human MSC. ${ }^{10}$ In equines, more than 60000 cells could be achieved after 1 week of culture. ${ }^{11}$ The differences might suggest that MSC expansion is species-dependent.

Many factors have been reported to influence MSC expansion rate. Appropriate cells source, culture medium (including fetal calf serum quality, glucose concentration, stable glutamine), hypoxic condition, seeding densities, TC flask size, plastic surface quality, and addition of growth factor may influence the expansion rate..$^{10-16}$

We used low-glucose DMEM (DMEM-LG) as the basal medium of culture in this study. This medium is reported to be able to support MSC growth and maintain population doubling time. ${ }^{17}$ Cell confluence could be achieved earlier when cultured in Mesencult $\AA$, however, it failed to support human MSCs growth beyond five passages. After 10 passages, the morphology of the MSC cultured in DMEM-LG also significantly changed to a leaf-like, flat and granulated phenotype. ${ }^{17}$ The characteristics surface markers expression also decreased. ${ }^{17}$ DMEM-LG is also reported to be inferior to $\alpha$-MEM in cell number yield. ${ }^{18} \mathrm{Pal}$ et al. suggested that knockout DMEM and DMEM-F12 supplemented with $10 \%$ FBS were the optimum and suitable culture medium for MSC isolation and expansion. ${ }^{17}$ Another factor that might take responsibility for the lower expansion rate in our study was the size of the tissue culture flask used to isolate the MSC. Chen et al. compared the usage of $25 \mathrm{ml}$ and $75 \mathrm{ml}$ flask and found that the best condition for the MSC isolation was achieved using $25 \mathrm{ml} \mathrm{flask.}{ }^{16}$ 
In our study, bone marrow of the femoral shaft showed insignificant different potency compared to bone marrow of iliac crest. This finding is contradictory to the common belief that yellow marrow is a poor source of mesenchymal stem cells. ${ }^{18}$ If yellow marrow does have the same potency as red marrow as the source of mesenchymal stem cells, obtaining cells from the fracture site offers many advantages. Surgery can be focused on the fracture site and morbidity at the donor site, specifically at the iliac crest, will be eliminated.

Although our findings might reflect that yellow marrow shared the same potency with red marrow as mesenchymal stem cell source, it should be noticed that some bias might influence our study. The procedure by which we obtain the marrow was slightly different. Marrow of the iliac crest was aspirated percutaneously in a blinded fashion, while marrow of the femoral shaft was aspirated openly. Blind aspiration might result in more bleeding, thus less cells were aspirated. This might also be the probable explanation to the finding that more plastic-adherent cells were achieved from femoral shaft than from iliac crest.

Plastic-adherent cell isolation in our study was performed using gravity separation technique without the use of a density gradient. This technique was reported to result in four fold higher mononuclear cell recovery and is less time consuming. ${ }^{19}$ However, we couldn't determine the number of mononuclear cells isolated because they were covered by the red blood cells. We therefore couldn't confirm whether the larger number of plastic-adherent cells in marrow isolated and expanded from femoral shaft was due to the larger number of mononuclear cells aspirated at the beginning of the study.

Other limitation to our study is that cell count was performed manually using improved Neubauer hemocytometer. Although the count was performed blindly, it would be more objective if they were counted using computerized equipment. We also did not characterize the cells either by surface antigen expression nor multi-lineage differentiation capacity.

In conclusion, marrow of the femoral shaft contains not less plastic-adherent cells than marrow of iliac crest $\left(3.7 \pm 2.50 \times 10^{4}\right.$ vs. $\left.2.93 \pm 0.91 \times 10^{4}\right)$. Since it offers many advantages, it may serve as a potential donor site for the isolation and expansion of plastic-adherent cells. However, another well prepared study involving human subject and considering age factor should be performed to confirm our finding.

\section{Acknowledgments}

The authors would like to acknowledge the Directorate of Research and Public Service (DRPM) University of Indonesia and Research Manager of the Faculty of
Medicine University of Indonesia for providing the research fund, The Department of Histology, Faculty of Medicine, University of Indonesia for providing the animal lab and technical assistance, and the Institute of Human Virology and Cancer Biology of the University of Indonesia (IHVCB-UI) for the laboratory work and assistance.

\section{REFERENCES}

1. Lee HB, Chung YS, Heo SY, Kim NS. Augmentation of bone healing in non-union fracture using stem cell based tissue engineering in a dog: a case report. Veterinari Med. 2009;54:198-203.

2. Kon E, Muraglia A, Corsi A, Bianco P, Marcacci M, Martin I, et al. Autologous bone marrow stromal cells loaded onto porous hydroxyapatite ceramic accelerate bone repair in critical-size defects of sheep long bones. J Biomed Mater Res. 2000;49:328-37.

3. Arinzeh TL, Peter SJ, Archambault MP, van den Bos C, Gordon S, Kraus K, et al. Allogeneic mesenchymal stem cells regenerate bone in a critical-sized canine segmental defect. J Bone J Surg (As). 2003;85:1927-35.

4. Fennema E, Rennard AJS, Leusink A, van Blitterswijk CA, De Boer J. The effect of quality of bone marrow aspiration strategy on the yield and quality of human mesenchymal stem cells. Acta Orthop. 2009;80:618-21.

5. Colter DC, Class R, Digirolamo CM, Prockop DJ. Rapid expansion of recycling stem cells in cultures of plasticadherent cells from human bone marrow. Proc Natl Acad Sci. 2000;97:3213-8.

6. Dominici M, Le Blanc K, Mueller I, Slaper-Cortenbach I, Marini FC, Krause DS, et al. Minimal criteria for defining multipotent mesenchymal stromal cells. The International Society for Cellular Therapy position statement. Cytotherapy. 2006;8(4):315-7.

7. Iwakura T, Miwa M, Sakai Y, Niikura T, Lee SY, Oe K, et al. Human hypertrophic non-union tissue contains mesenchymal progenitor cells with multilineage capacity in vitro. J Orthop Res. 2009;27(2):208-15.

8. Leonardi E, Devescovi V. Perut F, Ciapetti G, Giunti A. Isolation, characterization and osteogenic potential of human bone marrow stromal cells derived from the medullary cavity of the femur. Chir Organi Mov. 2008; 92:97-103.

9. Ciapetti G, Ambrosio L, Marletta G, Baldini N, Giunti A. Human bone marrow stromal cells; In vitro expansion and differentiation for bone engineering. Biomaterials. 2006;27:6150-60.

10. Both SK, Vander Muijsenberg ADJ, Van Blitterswijk CA, de Boer J, de Bruijn JD. A rapid and efficient method for expansion of human mesenchymal stem cells. Tissue Eng. 2007;13:3-9.

11. Colleoni S, Bottani E, Tessaro I, Mari G, Merlo B, Romagnoli N, et al. Isolation, growth and differentiation of equine mesenchymal stem cells: effect of donor, source, amount of tissue and supplementation with basic fibroblast growth factor. Vet Res Commun. 2009; 33:811-21.

12. Farre J, Roura S, Prat-Vidal C, Solerbotija C, Annallach, Molina CE, et al. FGF-4 increases in vitro expansion rate of human adult bone marrow derived mesenchymal stem cells. Growth Factors. 2007; 25(2): 71-6.

13. Sung JH, Yang HM, Park JB, Choi GS, Joh JW, Kwon CH, et al. Isolation and characterization of mouse mesenchymal stem cells. Transplant P. 2008; 40: 2649-54. 
14. Sotiropoulou PA, Perez SA, Salagianni M, Baxevanis $\mathrm{CN}$, Papamichail $\mathrm{M}$. Characterization of the optimal culture conditions for clinical scale production of human mesenchymal stem cells. Stem Cells. 2006;24:462-71.

15. Dos Santos F, Andrade PZ, Boura JS, Abecasis MM, Da Silva CL, Cabral JMS. Ex vivo expansion of human mesenchymal stem cells: a more effective cell proliferation kinetics and metabolism under hypoxia. J Cell Physiol. 2010;223:27-35.

16. Chen HH, Devot V, Ouyang JP, Stotlz JF, Bensoussan D, de Isla NG. In vitro initial expansion of mesenchymal stem cells is influenced by the culture parameters used in the isolation process. Biom Mater Eng. 2009;19:301-9.
17. Pal R, Hanwate M, Jan M, Totey S. Phenotypic and functional comparison of optimum culture conditions for up scaling of bone marrow-derived mesenchymal stem cells. J Tissue Eng Regen Med. 2009; 3: 163-74.

18. Gurevitch O, Slavin S, Resnick I, Khitrin S, Feldman A. Mesenchymal progenitor cells in red and yellow bone. Folia Biol. 2009;55: 27-34.

19. Dal Pozzo S, Urbani S, Mazzanti B, Luciani P, Deledda C, Lombardini L. High recovery of mesenchymal progenitor cells with non-density gradient separation of human bone marrow. Cytotherapy. 2010; Mar 30 [Epub ahead of print] 